JPdK Volume 2 No 1 Tahun 2020 Halaman 81-85

JURNAL PENDIDIKAN dan KONSELING

Research \& Learning in Primary Education

UNIVERSITAS

\title{
Pengaruh Budya Literasi Sekolah Melalui Pemanfaatan Sudut Baca Terhadap Minat Membaca Siswa Di Sekolah Dasar
}

\author{
Fransiska Ayuka Putri Pradana \\ Pendidikan Guru Sekolah Dasar \\ FakultasKeguruan dan Ilmu Pendidikan \\ Universitas Kristen Satya Wacana Salatiga \\ Email: 292017037@student.uksw.edu
}

\begin{abstract}
Abstrak
Dalam Undang - Undang Sistem Pendidikan Nasional No. 20 Tahun 2003 Pasal 4 ayat 5 menyebutkan bahwa Pendidikan diselenggarakan dengan mengembangkan budaya membaca, menulis, dan berhitung bagi segenap warga masyarakat. Oleh karena itu dalam menerapkan budaya literasi, sekolah memanfaatkan sudut baca yang ada di kelas dengan tujuan untuk memanfaatkan minat baca peserta didik.Penelitian ini menggunakan metode studi pustaka dengan mengumpulkan informasi dari beberapa artikel ilmiah.Langkah yang digunakan yaitu dengan mencari informasi mengenai penelitian, menentukan topik permasalahan dan rumusan masalah, mencari sumber data berupa artikel ilmiah yang relevan, membaca dan mencatat informasi yang didapat, dan menyusun penelitian artikel untuk menjawab rumusan masalah.Tujuan dari penulisan artikel ini adalah untuk mengetahui pemanfaatan sudut baca dalam meningkatkan minat baca peserta didik yang dilakukan dengan kegiatan membaca 15 menit sebelum pembelajaran dimulai.Selain itu mengetahui dampak pemanfaatan sudut baca yang dapat meningkatkan minat membaca dan kreativitas peserta didik dan hambatan dalam pemanfaatan sudut baca yaitu kurangnya koleksi buku dan kurangnya semangat untuk membaca.
\end{abstract}

Kata Kunci :Budaya Literasi, Sudut Baca Kelas, Minat Baca Peserta Didik.

\begin{abstract}
The laws of the Sisdiknas No. 20, 2003 states that education is established by developing a culture of reading, writing, and counting for all citizens. In implementing a literacy culture, the school utilizes the reading corners of the class with the aim of taking advantage of learners' reading interests. The study use a literary method for collecting information from some scientific articles. The step used is to get information about research, determine the subject of problems and problem formulations, find the source of data in relevant scientific articles, read and record the information received, and draft a study of articles to solve problems problems. The purpose of this article is to identify the use of punctuation in boosting learners' interest in reading activities 15 minutes before learning begins. The effect of literacy utilization that can increase learners interest in reading and creativity and that of barriers to reading corners is that of lack of books and lack of enthusiasm for reading.
\end{abstract}


Keywords : Cultural literacy,class reading corner, student interest in reading.

\section{PENDAHULUAN}

Pendidikan merupakan kebutuhan yang sangat penting dalam kehidupan manusia, karena melalui pendidikan mampu membentuk watak yang bermartabat serta peradaban guna mencerdaskan kehidupan bangsa . Dalam Undang - Undang Sistem Pendidikan Nasional (Sisdiknas) No. 20 Tahun 2003 Pasal 4 ayat 3 sampai 5 menyebutkan bahwa Pendidikan diselenggarakan sebagai suatu proses pembudayaan dan pemberdayaan peserta didik yang berlangsung sepanjang hayat. Pendidikan diselenggarakan dengan memberi keteladanan, membangun kemauan, dan mengembangkan kreativitas peserta didik dalam proses pembelajaran. Pendidikan diselenggarakan dengan mengembangkan budaya membaca, menulis, dan berhitung bagi segenap warga masyarakat. Berdasarkan Undang - Undang tersebut, maka pemerintah mengembangkan budaya membaca dengan mengeluarkan Peraturan Menteri pendidikan dan kebudayaan (Permendikbud) Nomor 23 Tahun 2015 tentang Penumbuhan Budi pekerti Luhur kepada peserta didik dengan mengembangkan Gerakan Literasi Sekolah (GLS). Gerakan Literasi Sekolah ini dilakukan dengan tujuan untuk meningkatkan minat membaca peserta didik.Budaya literasi adalah budaya keberaksaraan, yaitu suatu kemampuan seseorang dalam mengerti dan menggunakan baca tulis (Sutarno, 2008).Istilah literasi umumnya mengarah pada kemampuan atau keterampilan membaca dan menulis.Namun pada umumnya penguasaan keterampilan membaca lebih baik dari keterampilan menulisnya (Ilzamudin, 2010).Minat baca merupakan dorongan untuk memahami kata demi kata dan isi yang terkandung dalam teks bacaan (Dalman, 2017). Menurut Marksheffel membaca adalah kegiatan kompleks dan disengaja, kegiatan ini berupa proses berpikir yang terdiri dari berbagai pikiran yang bekerja secara terpadu mengarah kepada satu tujuan yaitu memahami makna paparan tertulis secara keseluruhan. Dalam hal ini, kegiatan membaca mengarah pada kegiatan memperoleh pengetahuan dari simbol-simbol huruf atau gambar yang diamat, pemecahan masalah yang timbul serta menginterprestasikan simbol-simbol huruf atau gambar-gambar dan sebagainya.

Menurut data UNESCO dalam riset bertajuk World's Most Literate Nations Ranked yang dilakukan oleh Central Connecticut state University pada Maret 2016, Indonesia dinyatakan menduduki peringkat ke-60 dari 61 negara soal minat membaca. UNESCO menyebutkan bahwa indeks minat baca di Indonesia baru mencapai 0,001 yang artinya setiap 1000 penduduk hanya satu yang memiliki minat baca.Menurut Tarigan (2008) faktor yang mempengaruhi minat baca yaitu faktor penyediaan waktu untuk membaca dan pemilihan bacaan yang baik. Menurut Masjidi (2007) terdapat beberapa faktor yang mempengaruhi minat baca pada anak, anatara lain keluarga dan lingkungan di luar keluarga berperan penting dalam menumbuhkan minat bica seseorang. Triatma (2016) menjelaskan bahwa rendahnya minat baca disebabkan oleh beberapa hal diantaranya mahalnya harga buku dan terbatasnya fasilitas terpustakaan.Oleh karena itu, sekolah harus bisa memfasilitasi berbagai sarana yang dapat meningkatkan minat baca siswa yaitu dengan memanfaatkan perpustakaan sekolah. Faktor lain yang menyebabkan rendahnya minat baca peserta didik antara lain adalah lingkungan belajar yang tidak mendukung, tingginya harga buku yang memberatkan peserta didik, fasilitas perpustakaan sekolah yang kurang memadai, dan akibat negatif dari perkembangan teknologi yaitu gadget. Dampak negatif dari perkembangan teknologi gadget dapat mengurangi kebersamaan dan interaksi serta komunikasi secara langsung antar individu. Peserta didik lebih tertarik 
untuk bermain game online melalui gadget daripada membaca buku. Hal ini dapat menyebabkan rendahnya minat peserta didik untuk membaca.

Dalam menerapkan program gerakan Literasi Sekolah sebagai kebijakan dari Kementrian Pendidikan dan kebudayaan, sekolah dapat mengembangkan budaya literasi untuk meningkatkan minat baca peserta didik dengan menciptakan dan memanfaatkan sudut baca atau yang biasa disebut dengan perpustakaan kelas. Kemendikbud (2016) menjelaskan tujuan sudut baca yaitu untuk mengenalkan kepada siswa beragam sumber bacaan untuk dimanfaatkan sebagai media, sumber belajar, serta memberikan pengalaman membaca yang menyenangkan.Sudut baca juga sebagai upaya mendekatkan perpustakaan ke siswa. Sudut baca dimanfaatkan secara optimal untuk mendukung keberhasilan proses pembelajaran.Peserta didik dapat memanfaatkan sudut baca tersebut untuk memperkaya pengetahuannya. Menurut pengamatan yang penulis lakukan dalam kegiatan magang di sekolah dasar, rendahnya minat peserta didik untuk membaca dan berkunjung ke perpustakaan sekolah dikarenakan tidak adanya waktu bagi peserta didik untuk membaca buku di perpustakaan serta keterbatasan tempat di perpustakaan sekolah. Saat istirahat peserta didik lebih Penelitian ini menggunakan metode penelitian jenis kajian pustaka atau studi kepustakaan yang bersifat kualitatif. Metode studi kepustakaan adalah metode yang dilakukan dengan cara mengumpulkan sejumlah informasi atau data melalui buku, artikel, karya ilmiah, dan sumber relevan lain yang dapat menunjang penulisan artikel. Penelitian yang bersifat kualitatif ini berupa deskripsi atau uraian yang dilakukan dengan membaca dan menggali informasi melalui sumber data.Dalam menyusun artikel ini menggunakan sumber data berupa artikel artikel yang diambil dalam jurnal ilmiah dan beberapa buku relevan lainnya. Kegiatan yang dilakukan dalam penelitian ini yaitu : (1) mencari informasi mengenai penelitian, memilih untuk berada di kelas dan bermain bersama teman dibandingkan dengan berkunjung dan membaca buku ke perpustakaan sekolah.

Budaya literasi di sekolah dapat berupa kegiatan membaca selama 15 menit sebelum waktu pembelajaran dimulai. Peserta didik juga dapat memanfaatkan waktu istirahat atau waktu luang ketika telah selesai menyelesaikan tugas dengan membaca buku di sudut baca bersama peserta didik yang lain. Dalam pemanfaatan sudut baca, tidak hanya berisi buku pelajaran saja, namun bisa juga diberi buku cerita, majalah, koran, ensiklopedia, dan lain sebagainya.

Berdasarkan permasalahan yang telah dijelaskan di atas mengenai rendahnya minat baca peserta didik di Indonesia, penulis merumuskan hal yang perlu dibahas yaitu mengenai pemanfaatan sudut baca untuk meningkatkan minat baca peserta didik, dampak pemanfaatan sudut baca di setiap kelas bagi peserta didik dan faktor penghambat dalam pemanfaatan sudut baca. Untuk itu, dalam artikel ini penulis akan membahas mengenai tiga hal tersebut berdasarkan sumber dari artikel ilmiah lain yang digunakan dalam menyusun artikel studi pustaka ini.

\section{METODOLOGI PENELITIAN}

(2) menentukan topik permasalahan dan rumusan masalah, (3) mencari sumber data berupa artikel ilmiah yang relevan, (4) membaca dan mencatat informasi yang didapat dari sumber data, (5) dan menyusun penelitian artikel untuk menjawab rumusan masalah.

\section{HASIL PENELITIAN DAN PEMBAHASAN}

Berdasarkan hasil analisis dari 6 artikel yang berjudul Pemanfaatan Sudut Baca dalam Meningkatkan Minat Baca Siswa di Madrasah Ibtidaiyah Negeri 2 Samarinda yang ditulis oleh Nadya N. R. dan Siti J., Dampak Perpustakaan Kelas di SDN 1 
Kutosari Kebumen yang ditulis oleh Alfi Nur H, Laras M., dan Moh Salimi, Analisis Gerakan Literasi Pojok Baca Kelas terhadap Eksistensi Daya Baca Anak di Sekolah Dasar yang ditulis oleh Hijrawatil Aswat dan Andi Lely Nurmaya, Membangun Budaya Baca Melalui Pengelolaan Media Sudut Baca Kelas Dengan "12345" yang ditulis oleh Mijiatun Sri Hartyatni, Optimalisasi Fungsi Pojok Baca di Kelas I SD Muhammadiyah Pangkalpinang sebagai Penumbuhkenalkan Budaya Membaca yang ditulis oleh Bintang Pamungkas, dan Gerakan Literasi Sekolah (GLS) melalui Pemanfaatan Sudut Baca Kelas sebagai Sarana Alternatif Penumbuhan Minat Baca Siswa yang ditulis oleh Febriana Ramandanu. Artikel tersebut digunakan sebagai sumber dalam menulis artikel ini. Penulis akan membahas mengenai pemanfaatan sudut baca dalam meningkatkan minat baca peserta didik, dampak pemanfaatan sudut baca bagi peserta didik, dan faktor penghambat dalam pemanfaatan sudut baca.

\section{Pemanfaatan Sudut Baca dalam Meningkatkan Minat Baca Siswa}

Berdasarkan hasil analisis dari artikel ilmiah yang ditulis oleh Nadya N. R. dan Siti J. yang berjudul Pemanfaatan Sudut Baca dalam Meningkatkan Minat Baca Siswa di Madrasah Ibtidaiyah Negeri 2 Samarinda menyatakan bahwa dalam memanfaatkan sudut baca sudah berjalan dengan baik, walaupun buku - buku yang disediakan masih belum mencukupi tetapi pemanfaatannya tetap dijalankan. Dalam memanfaatkan sudut baca, guru mengadakan kegiatan membaca selama kurang lebih 15 menit setiap harinya.Kegiatan membaca ini dilakukan sebelum pembelajaran dimulai.Pada awal kegiatan banyak siswa yang masih malas dan tidak tertarik untuk membaca, karena mereka terbiasa bermain dengan temannya.Dalam membiasakan siswa untuk mau membaca di sudut baca, guru memerlukan waktu yang cukup lama.

Timbulnya minat terhadap suatu

objek ditandai dengan adanya rasa
ketertarikan.Dalam kegiatan membaca ini, peneliti melihat antusias minat peserta didik dalam membaca di sudut baca.Pada awalnya, guru memberikan dorongan kepada peseta didik untuk mulai membaca.Akhirnya peserta didik mulai menyukai kegiatan membaca melalui sudut baca.Minat membaca siswa ditandai dengan keaktifan siswa dalam mengunjungi sudut baca serta membaca buku bacaan yang ada di sudut baca. Pemanfaatan sudut baca di MI Negeri 2 Samarinda dilaksanakan dengan beberapa cara, yaitu :

a. Penyusunan buku harus rapi dan menarik.

b. Adanya buku bacaan cerita atau nonfiksi.

c. Penyusunan tata ruang harus sesuai.

d. Motivasi dan dorongan oleh guru kepada siswa untuk selalu membaca.

Hasil analisis lainnya mengenai pemanfaatan sudut baca dalam meningkatkan minat membaca peserta didik adalah analisis dari artikel berjudul Dampak Perpustakaan Kelas di SDN 1 Kutosari Kebumen yang ditulis oleh Alfi Nur H, Laras M., dan Moh Salimi.Dalam artikel ini, perpustakaan kelas yang dilaksanakan dikategorikan menjadi dua, yakni area baca dan sudut baca.Sudut baca yaitu sudut yang ada di kelas dan dilengkapi dengan koleksi buku untuk menarik dan menumbuhkan minat baca siswa, sedangkan area baca meliputi lingkungan sekolah berupa serambi yang dilengkapi dengan koleksi buku.Dalam pemanfaatannya, pembiasaan budaya literasi melalui sudut baca kelas ini dilaksanakan setiap Senin dan Sabtu.Peserta didik dijadwalkan untuk dating lebih awal pada pukul 06.30 dan melakukan kegiatan membaca bersama selama 30 menit.Selain itu pemanfaatan sudut baca juga dilakukan pada saat istirahat maupun saat pembelajaran yang melibatkan penggunaan sudut baca.

Analisis artikel berjudul Analisis Gerakan Literasi Pojok Baca Kelas terhadap Eksistensi Daya Baca Anak di Sekolah Dasar yang ditulis oleh Hijrawatil Aswat dan Andi Lely Nurmaya menerapkan pemanfaatan sudut baca yaitu dengan cara menerapkan kegiatan 15 menit membaca memulai pelajaran. Kegiatan lain dalam memanfaatkan 
sudut baca yaitu dengan menggunakannya pada saat istirahat atau waktu senggang saat pembelajaran berlangsung. Dalam hal ini maka pemanfaatan sudut baca dapat dikatakan sudah efektif.

Pemanfaatan sudut baca menurut analisis dalam artikel yang berjudul Membangun Budaya Baca Melalui Pengelolaan Media Sudut Baca Kelas Dengan "12345" oleh Mijiatun Sri Hartyatni adalah dengan membaca buku pelajaran pada jam pertama selama 10-15 menit serta membaca dan mengisi mading sekolah. Kegiatan membaca dilakukan dalam kegiatan pembelajaran dengan tema tertentu yang disepakati dan dimasukkan dalam program pengelolaan membaca.

Menurut analisis artikel berjudul Optimalisasi Fungsi Pojok Baca di Kelas I SD Muhammadiyah Pangkalpinang sebagai Penumbuhkenalkan Budaya Membaca oleh Bintang Pamungkas menjelaskan bahwa sudut baca terbukti bisa dimanfaatkan oleh peserta didik untuk mengisi waktu luang atau saat istirahat berlangsung. Sudut baca juga dapat dijadikan tempat untuk menciptakan suasana kelas yang kondusif saat pembelajaran.Buku yang terdapat pada rak buku sudut baca adalah buku koleksi peserta didik sendiri, sehingga mereka dapat bertukar buku dengan teman - temannya.

Artikel lain berjudul Gerakan Literasi Sekolah (GLS) melalui Pemanfaatan Sudut Baca Kelas sebagai Sarana Alternatif Penumbuhan Minat Baca Siswa yang ditulis oleh Febriana Ramandanu menjelaskan bahwa pelaksanaan gerakan literasi sekolah di SD Negeri Pamongan 2 pada tahap pembiasaan dilakukan melalui kegiatan membaca selama 15 menit sebelum pembelajaran dimulai. Kegiatan membaca selama 15 menit adalah program wajib yang diikuti oleh semua warga sekolah.Kegiatan ini bertujuan untuk menciptakan lingkungan yang mendukung untuk menumbuhkan minat baca peserta didik.Kegiatan membaca 15 menit dilaksanakan dengan memanfaatkan sudut baca yang terdapat di setiap sudut kelas.Sudut baca kelas pada kelas rendah memiliki koleksi buku-buku non pelajaran, diantaranya buku dongeng bergambar, cerita rakyat bergambar dan buku kata kartun. Sementara pada kelas tinggi memiliki sudut baca kelas yang tertata dengan rapi, bersih dan memiliki koleksi novel, kumpulan puisi, kumpulan pantun, komik, majalah bobo, dan buku pelajaran

\section{Dampak Pemanfaatan Sudut Baca Bagi Peserta Didik}

Hasil analisis artikel ilmiah berjudul Pemanfaatan Sudut Baca dalam Meningkatkan Minat Baca Siswa di Madrasah Ibtidaiyah Negeri 2 Samarinda yang ditulis oleh Nadya N. R. dan Siti J., menyebutkan bahwa pemanfaatan sudut baca memiliki beberapa dampak positif bagi peserta didik yaitu dapat menanamkan pembiasaan membaca buku pada peserta didikdan memingkatkan minat membaca peserta didik, karena pada saat ini Indonesia merupakan salah satu negara dengan minat membaca yang rendah. Hal ini ditandai dengan seringnya peserta didik untuk berkunjung ke sudut baca dan merasa senang saat membaca.

Artikel lain yang berjudul Dampak Perpustakaan Kelas di SDN 1 Kutosari Kebumen yang ditulis oleh Alfi Nur H, Laras M., dan Moh Salimi menjelaskan bahwa sudut baca kelas membawa dampak yang beragam bagi peserta didik, antara lain:

a. Dengan adanya sudut baca di kelas, minat membaca peserta didik meningkat. Hal ini didukung oleh pernyataan kepala sekolah yaitu dengan adanya perpustakaan di sudut kelas, peserta didik sering memanfaatkan waktunya untuk membaca.

b. Kreativitas peserta didik semakin bertambah karena sering membaca literatur yang berkaitan dengan seni dan keterampilan, maupun buku pengetahuan lain yang tersedia di perpustakaan kelas. Hal ini dibuktikan dengan beragamnya karya - karya peserta didik yang dipajang baik di majalah dinding maupun di lemari pajang. 
c. Bakat peserta didik menjadi berkembang. Hal ini didukung oleh pernyataan dari kepala sekolah yaitu banyak bakat - bakat ditemukan pada peserta didik melalui budaya membaca yang dikembangkan di sekolah.

Analisis artikel berikutnya yang berjudul Analisis Gerakan Literasi Pojok Baca Kelas terhadap Eksistensi Daya Baca Anak di Sekolah Dasar yang ditulis oleh Hijrawatil Aswat dan Andi Lely Nurmaya juga menyebutkan bahwa dalam pemanfaatan sudut baca di kelas juga memiliki dampak terhadap minat baca anak yang ditandai dengan antusias siswa dan motivasi membacanya. Dari angket yang diberikan ke peserta didik disimpulkan bahwa peserta didik sangat senang dengan adanya sudut baca karena mereka merasa lebih dekat dengan sumber belajar dan senang membaca buku bersama teman - temannya, mereka dapat berlomba dalam menyelesaikan bacaannya lalu menceritakan kembali.

Dampak pemanfaatan sudut baca menurut Mijiatun Sri Hartyatni dalam artikelnya yang berjudul Pemanfaatan sudut baca menurut analisis dalam artikel yang berjudul Membangun Budaya Baca Melalui Pengelolaan Media Sudut Baca Kelas Dengan "12345" adalah mudahnya peserta didik dalam mengakses pembelajaran karena letak koleksi buku dekat dengan siswa, selain itu dengan adanya kegiatan membawa selama 10-15 menit juga dapat membantu siswa dalam meningkatkan minat membaca.

Artikel lain berjudul Optimalisasi Fungsi Pojok Baca di Kelas I SD Muhammadiyah Pangkalpinang sebagai Penumbuhkenalkan Budaya Membaca oleh Bintang Pamungkas menjelaskan mengenai dampak adanya sudut baca di kelas yaitu untuk menumbuhkan kreativitas peserta didik dengan cara menceritakan kembali cerita yang mereka baca. Para guru dan pustakawan menyadari pentingnya story telling bagi peserta didik. Mereka memberikan pendapat bahwa dengan kesediaan peserta didik untuk menceritakan kembali cerita yang mereka baca akan membuat mereka percaya diri dan meningkatkan kemampuan mereka dalam berkomunikasi.

Analisis artikel yang berjudul Gerakan Literasi Sekolah (GLS) melalui Pemanfaatan Sudut Baca Kelas sebagai Sarana Alternatif Penumbuhan Minat Baca Siswa yang ditulis oleh Febriana Ramandanu menyebutkan bahwa Pengembangan dan penataan perpustakaan kelas, adalah hal penting dari pelaksanaan GLS. Tempat literasi berupa sudut baca yang dikelola dengan baik mampu meningkatkan minat baca dan menjadikan warga sekolah sebagai pembelajar sepanjang hayat.Dampak dari pemanfaatan sudut baca bagi peserta didik kelas rendah yaitu untuk melatih kosa kata sehingga dapat meningkatkan kemampuan membaca peserta didik.Sedangkan untuk kelas tinggi, dampak pemanfaatan suduta baca adalah melatih kreativitas peserta didik dalam menulis karya sastra.

\section{Faktor Penghambat dalam Pemanfaatan Sudut Baca}

Hasil analisis artikel ilmiah berjudul Pemanfaatan Sudut Baca dalam Meningkatkan Minat Baca Siswa di Madrasah Ibtidaiyah Negeri 2 Samarinda yang ditulis oleh Nadya N. R. dan Siti J., dalam memanfaatkan sudut baca ada beberapa faktor penghambat yang mempengaruhi pemanfaatan sudut baca, antara lain adalah kurangnya tempat untuk membuat sudut baca yang lebih luas di setiap kelas dan kurangnya jenis buku yang ada. Oleh karena itu peserta didik akan merasa bosan jika terus membaca buku yang sama.

Menurut hasil analisis artikel yang berjudul Dampak Perpustakaan Kelas di SDN 1 Kutosari Kebumen yang ditulis oleh Alfi Nur H, Laras M., dan Moh Salimi.Faktor yang menghambat dalam pemanfaatan sudut baca adalah rendahnya semangat peserta didik untuk membaca serta mempunyai rasa bosan terhadap buku yang telah mereka baca, 
untuk itu guru harus lebih berperan aktif dalam mendorong peserta didik untuk melaksanakan program membaca dengan telaten, sering mengingatkan, dan mendampingi siswa dalam membaca.Hal tersebut dapat membantu peserta didik untuk menumbuhkan semangat dalam membaca. Selain itu untuk mengatasi permasalahan bosannya peserta didik dalam membaca buku yang kurang beragam, maka pengurus perpustakaan bekerja sama dengan wali kelas untuk mengganti buku yang ada dalam sudut baca.

Analisis artikel berjudul Analisis Gerakan Literasi Pojok Baca Kelas terhadap Eksistensi Daya Baca Anak di Sekolah Dasar yang ditulis oleh Hijrawatil Aswat dan Andi Lely Nurmaya juga menyebutkan berbagai faktor yang menjadi penghambat dalam pemanfaatan sudut baca yaitu minimnya kreativitas dalam mendesain sudut baca, siswa memiliki motivasi rendah dalam membaca yang akan menghambat daya pikir dan pemahamannya dalam menangkap pembelajaran. Untuk itu seorang guru harus secara kreatif mendesain pojok baca dalam kelas yang menarik dan nyaman.Terkadang ada peserta didik yang termotivasi untuk membaca dan ada yang tidak termotivasi, mereka senang melihat-lihat buku namun tidak memiliki daya baca yang baik yang ditandai dengan hanya membaca bagianbagian pokok buku saja.Peserta didik lebih senang bermain bersama teman daripada membaca buku dengan alasan sudah membaca semua buku yang ada.Untuk itu sebaiknya guru mengganti koleksi buku agar peserta didik bisa membaca buku yang beragam.

Faktor yang menjadi penghambat dalam pemanfaatan sudut baca menurut Mijiatun Sri Hartyatni dalam artikelnya yang berjudul Pemanfaatan sudut baca menurut analisis dalam artikel yang berjudul Membangun Budaya Baca Melalui Pengelolaan Media Sudut Baca Kelas Dengan "12345" adalah tidak adanya komitmen dengan waktu yang digunakan, kurangnya koordinasi dengan guru pada jam pertama hari itu, ada peserta didik yang tidak hadir dan banyak yang lupa waktu dan tidak ditegur. Untuk itu seharusnya guru dapat mengatur pelaksanaan kegiatan membaca agar dapat berjalan dengan lancar.

Analisis artikel berjudul Optimalisasi

Fungsi Pojok Baca di Kelas I SD Muhammadiyah Pangkalpinang sebagai Penumbuhkenalkan Budaya Membaca oleh Bintang Pamungkas menjelaskan faktor yang menjadi penghambat dalam pemanfaatan pojok baca adalah peran orang tua yang belum mampu menjadi model yang baik untuk anak mereka dalam kegiatan mengembangkan literasi dini. Menurut hasil penelitian dari responden yang diteliti menyatakan bahwa orang tua sering melakukan kegiatan menonton tv dan bermain gadget daripada membaca buku. Selain itu masih terdapat beberapa peserta didik yang belum lancer dalam membaca.Untuk itu, dapat dilakukan kegiatan dengan meminta siswa untuk mengumpulkan buku agar orang tua juga lebih peduli terhadap kebutuhan membaca peserta didik.

Menurut hasis analisis artikel yang berjudul Gerakan Literasi Sekolah (GLS) melalui Pemanfaatan Sudut Baca Kelas sebagai Sarana Alternatif Penumbuhan Minat Baca Siswa yang ditulis oleh Febriana Ramandanu menyebutkan bahwa faktor yang menghambat dalam pemanfaatan sudut baca sebagai budaya literasi yaitu kurangnya partisipasi orang tua dan masyarakat sekitar dalam menjalankan program literasi.Selain itu pemerintah juga kurang menunjang penyediaan sarana dan prasarana seperti buku - buku bacaan.

\section{SIMPULAN}

Berdasarkan hasil pembahasan yang telah dibahas mengenai pemanfaatan sudut baca dalam meningkatkan minat baca peserta didik, dampak pemanfaatan sudut baca, dan faktor yang menghambat pemanfaatan sudut baca yang diperoleh dari hasil analisis kajian artikel yang digunakan, dapat disimpulkan bahwa dalam memanfaatkan sudut baca untuk 
meningkatkan minat membaca peserta didik dilakukan dengan cara pembiasaan. Cara ini dilakukan dengan membiasakan peserta didik untuk membaca selama 15 menit sebelum pembelajaran dimulai.Sudut baca juga dapat digunakan oleh peserta didik saat beristirahat maupun waktu senggang pada saat pembelajaran.Sudut baca juga didesain dan ditata serapi mungkin agar peserta didik merasa nyaman untuk membaca.Buku yang ada di rak sudut baca juga beragam, yaitu terdiri dari buku pelajaran, cerita rakyat bergambar, novel, buku cerita anak, kumpulan pantun dan puisi, majalah, buku ensiklopedi, dan sebagainya.

Pemanfaatan sudut baca memiliki dampak positif, yaitu dapat menumbuhkan minat membaca peserta didik, hal ini dapat dibuktikan dengan banyaknya peserta didik yang membaca setelah diciptakannya pojok baca.Selain itu, sudut baca juga dapat meningkatkan kreativitas peserta didik.Dengan membaca buku bergenre sastra, mereka dapat menulis karya sastra dengan baik dan mampu menceritakan kembali buku yang telah dibaca.

Walaupun dalam pemanfaatan sudut baca memiliki dampak positif, namun terdapat faktor yang menghambat dalam pemanfaatannya yaitu kurangnya motivasi peserta didik dalam membaca, timbul rasa bosan dalam diri peserta didik untuk membaca karena buku bacaan yang kurang beragam, serta kurangnya partisipasi dari orang tua peserta didik dalam mendukung pelaksanaan literasi sekolah melalui sudut baca.

\section{DAFTAR PUSTAKA}

Aswat, H., dkk. 2020. ANALISIS GERAKAN LITERASI POJOK BACA KELAS TERHADAP EKSISTENSI DAYA BACA ANAK DI SEKOLAH DASAR. Jurnal Basicedu. 4(1) : 70-78.

Hartyatni, M. S. 2018. MEMBANGUN BUDAYA BACA MELALUI
PENGELOLAAN MEDIA SUDUT BACA KELAS DENGAN "12345". Jurnal Pemikiran dan Pengembangan SD. 6(1) : 1-11.

Hayati, Alfi N., dkk. 2017. DAMPAK PERPUSTAKAAN KELAS DI SEKOLAH DASAR DI SDN 1 KUTOSARI KEBUMEN. Sinta Indonesia Universitas Sebelas Maret

Kurniawan, Agung R., dkk. 2019. PERANAN POJOK BACA DALAM MENUMBUHKAN MINAT BACA SISWA SEKOLAH DASAR. Jurnal Inovasi Pendidikan dan Pembelajaran Sekolah Dasar. 3(2): 48-57.

Pamungkas, Bintang. 2018. OPTIMALISASI FUNGSI POJOK BACA DI KELAS I SD MUHAMMADIYAH PANGKALPINANG SEBAGAI PENUMBUHKENALKAN BUDAYA $M E M B A C A$. Skripi.Universitas Muhamadiyah Surakarta.

Ramadhanti, Nadya. 2019. PEMANFAATAN SUDUT BACA DALAM MENINGKATKAN MINAT BACA SISWA DI MADRASAH IBTIDAIYAH NEGERI 2 SAMARINDA. Jurnal Tarbiyah \& Ilmu Keguruan (JTIK) Borneo 1(1): 39-46.

Ramandanu, Febriana. 2019. GERAKAN LITERASI SEKOLAH (GLS) MELALUI PEMANFAATAN SUDUT BACA KELAS SEBAGAI SARANA ALTERNATIF PENUMBUHAN MINAT BACA SISWA. Jurnal Mimbar Ilmu Universitas Pendidikan Ganesha. 24(1) : 10-19.

Rofi'uddin, Moh Adib. 2017. PENGARUH POJOK BACA TERHADAP PENINGKATAN MINAT BACA SISWA DI SMP NEGERI 3 PATI. Jurnal Ilmu Perpustakaan. 6(1): 281-290.

Wirna. 2019. PENGELOLAAN SUDUT BACA DI LINGKUNGAN SEKOLAH DALAM MENUMBUHKAN BUDAYA 
LITERASI PADA SISWA MTSN 1 Islam Negeri Alauddin Makassar. KOTA MAKASSAR. Skripsi.Universitas 